\title{
RETROSPECTIVE ANALYSIS OF INTERNATIONALIZATION IN THE RESEARCH AND EDUCATION SPHERES
}

\author{
E.V. Evsina, elenachel@mail.ru \\ South Ural State University, Chelyabinsk, Russian Federation
}

\begin{abstract}
The problem of internationalization of higher education is considered on the basis of a retrospective analysis of the problem. This process is inseparable from the process of globalization in various areas of human activity. The evolution of the main trends in European education and the need to integrate national educational systems into the common-European educational environment is analyzed. The stages of the internationalization of higher education are singled out on the basis of common criteria: academic staff and students' mobility, common academic language, the increase of the number of universities. The EMI (English as a Medium of Instruction) program is considered as one of the results of the development of a single common European educational environment.

Keywords: internationalization, the readiness of academic staff for teaching international students, academic mobility, the EMI program (English as a language of academic disciplines).
\end{abstract}

To understand the state of the problem, we will turn to a retrospective analysis, which is due to the key task facing Russian universities: turning internationalization into a basic framework in the age of global competition. General definition of internationalization is the following: the transformation of something into the object of international law; granting under the contract to all states the right to use some object on an equal right [20]. But we will consider the process, according to OECD (Organization for Economic Cooperation and Development), in which the goals, functions and organization of educational services acquire an international dimension [7]. In other words, every university should form a clear understanding of the need for full internationalization and the development of appropriate rules and strategies. This process should be based on the idea of involving all members of the academic community - students, lecturers and everyone who provides this process. Besides, this process requires the development and provision of the tools necessary for the scientific community members for training, life and work in the global world.

Prerequisites for the internationalization of higher education are political, economic, social, cultural and academic factors, such as: economic growth and competition for promising markets, the development of information technologies and the formation of a global educational environment, the desire of countries to protect national security and acquire foreign policy advantages [33]. Under the influence of these and other factors, changes occur in the system of higher education: globalization and diversification of the sector, changes in funding system, increase in forming students and lecturers competencies importance. All these changes allow the education system to adapt to activities in a multicultural environment.

To understand the essence of the process under investigation it is necessary to turn to the history of its origin and development.

In our work, we will consider the process of internationalization in terms of the criteria, proposed by us:

- the presence of one (or several) universal language;

- mobility among students and lecturers of educational institutions;

- extension of educational process (the opening of new universities).

Let us turn to the historical aspect of the manifestation of these criteria. On the basis of the analysis we have identified several periods: I (the end of the XI-XVII centuries), II (XVIII mid. XX centuries), III (1950-1991), IV (from 1995- to the present moment).

The most important feature of the first period is that the development of science and education was due to the creation of the first medieval universities. They were created on the basis of church schools at the end of the XI - early XII centuries. The first information about the development of secular education dates back to the XII-XIII centuries. It is associated with the opening of the first European universities in Italy, England, France and Spain [1]. 
According to historical data in 1158, the Emperor of the Holy Roman Empire, Friedrich I Barbarossa established one of the first European universities in the Italian city of Bologna. At first, only jurisprudence was taught at the university, but soon it turned into the most authoritative law school. By the XII century, the number of students who came to Bologna from all European countries had increased to 10,000 [1].

At about the same time, the University of Paris was opened in 1215 as a result of the unification of several church schools. Originally it consisted of four faculties: free arts, canon law, medicine and theology, where students of various nationalities studied together. In 1257, theologian Robert de Sorbonne, the confessor of King Louis IX, the Saint, founded a theological college for children from poor families in Paris. The university has received the name of the Sorbonne [1].

The University in Salamanca which became a visiting card of Spain was founded in 1227. It was declared in the charter of King Alfonso X in 1243. The literature of Arabs and Jews was most actively studied at this university, while the students came from countries of Asia Minor [33].

The network of universities grew quite rapidly. If in the thirteenth century there were 19 universities in Europe, then in the next century 25 more were added to them (in Angers, Naples, Lisbon, Orleans, Pisa, Cologne, Prague, Vienna, Cracow and other cities) [12].

Since the time of the wandering scientists of the late Middle Ages and the Renaissance, universities have been viewed as a social and cultural phenomenon, the purpose of which was the dissemination of knowledge. By the middle of the 13th century, a unified system of universities had been developed in Europe, which was the result of the development of the union of students and lecturers created for mutual assistance and protection. Moreover, the universities formed a culture, based on the recognition of a scientists' special role in the life of society - the preservation of the internal unity of the Christian world, while they, like knights, defended this world from external enemies [17]. Many professors gave their lectures, traveling to different European universities throughout the year.

A specific feature of medieval universities was its over-national and democratic character, expressed in the fact that people of all ages, nationalities and social status could be at one student's desk. The teaching staff was an elite of education of that time, possessing the abilities and readiness of teaching students of different confessional, national and social statuses. At that time the so-called spontaneous mobility of students and academic staff, which was not complicated by linguistic problems, was growing, developing and was quite a common phenomenon. That was due to the fact that in those days Latin was a common language for teaching. Thus, we can say that mobility of students and lecturers was at a sufficiently high level. One more reason for that was the fact that there were not enough lecturers at medieval universities, and the students could choose the courses and programs they would like to study [12].

The second period is the time from the XVIII century until the middle of the XX century. It is the beginning and development of the "export" of education. Now we can observe the elements of the English and French education systems in their former colonies.

A vivid example can be the penetration of French influence into the countries of Indo-China, which began as far back as the XVII century with the appearance of the first Catholic missionaries in these countries - the French. The number of Catholic missions led by French priests and bishops increased in the XVIII century [8].

Another example is Britain with its huge colonial system. A new round for the development of Indochina was given by the First World War. The change in the economic system, manifested in the expansion of the plantation economy, the development of industry and the rapid increase in the number of workers in the country, required changes in the education system. The number of immigrant youth from Indochina who studied in France increased sharply. Returning from France to their homeland, the specialists built a system of education in accordance with the familiar French one. And it was quite common at that time to invite French professors to their local universities [24].

At the same time most universities established in the XIX and XX centuries, performed their traditional functions of forming professional groups and local elite, as well as the development of science and technology in the national environment.

By the same scheme, education was also exported to English colonies in America, Europe, the Mediterranean, Australia, Africa, India and other territories. In 1636 the Puritans founded Harvard College in America, and in 1701 the Yale University. In 1764, the Brown University was 


\section{Теория и методика профессионального образования}

opened, and in 1769 Dartmouth College. The first medical institutes appeared in the late XVIII century in New York and Philadelphia. The proportion of white colonists who immigrated from the British Isles (English, Scots, Irish and Welsh), at the end of the XVIII century was about $85 \%$ in America [12]. An acute interest in the problems of education caused by revolutionary events was due to the need to provide the developing economy with its own specialists and thus defend in this sphere real independence and the desire to form national factors in the sphere of spiritual and intellectual life. At the same time universities in colonies had close ties with the university movement in Europe. That is why the transfer of rational principles and the latest achievements of science and technology were brought to American continent. The academic staff of Europe was ready to bring the light of science through the oceans. The need for such contacts was also dictated by the fact that scientific ties with Britain were interrupted, and during military operations some colleges were destroyed or weakened by political contradictions and lost many lecturers. But at the same time there arose the idea of creating a national university, supported by several delegates of the constitutional convention of 1787 , and then formulated by B. Rash [18].

The spread of the English educational system in India attracted students from abroad. Most of them are from Nepal, Bhutan, Sri Lanka, Bangladesh, Maldives and Afghanistan. Also, students from Africa were interested in various levels of Indian education [29]. At the same time, many institutes provided training in any field. Thanks to the English language, which was used during the lectures, and the reasonable cost of education and residence, foreigners were often attracted to India, both for higher education and for making a career.

The more developed European countries expanded their influence to other countries. It helped to spread the higher education around the world [22].

The most important features in the development of university education in the second period were, firstly, its content that included natural sciences. Secondly, in the XVIII century the transition to national languages began. Thirdly, at the beginning of the nineteenth century, a number of European states proclaimed university autonomy. Fourthly, since the XVII century various special higher schools and institutes (military, forestry, agricultural, pedagogical, etc.) have been created in European countries. We can say that since the XVIII century the modern system of higher education has been developed in Western Europe [13].

The problem of the readiness of the academic staff for teaching foreign students for special professions (vocational training) had exacerbated, since there was a shortage of trained personnel. Especially it concerned the implementation of the educational process with the use of new forms and methods of teaching - seminars and laboratory classes, practical classes (especially in medical and technical education).

In general, the technological side of education in the XVII-XVIII centuries significantly changed and improved. This was facilitated by both the socio-cultural conditions that put forward new requirements for education and pedagogical factors, (first of all the beginning of mass training of teachers/ lecturers) and a change in the content of education, which required the search for new forms and methods of instruction.

The third period 1950-1991 is characterized by the involvement of universities in the powerful movement of educational "expansion" and the democratization of educational opportunities. Mass distribution of higher education began to be seen as a guarantee of the state's competitiveness in the new global world [25].

All these processes are reflected in the former Soviet Union. The internationalization of Higher education in our country began after the end of World War II. In the 1950s-1960s, during the development of national liberation movements, countries with developed economies tried to help the former colonies by preparing national academic staff. For this purpose, academic mobility programs were developed and implemented, for which foreign students were trained. These processes affected both Western and Eastern countries. The most striking example is the opening of the Lumumba Peoples' Friendship University in 1960, which hosted students from all over the world. The academic staff worked on the problem of readiness for teaching foreign students, taking into account their national mentality and the difficulties of teaching and learning the Russian language. It should be noted that, due to the geopolitical realities of that time, most foreign students in the former USSR, of course, were representatives of the socialist countries of Europe, as well as of Asia, Latin America and Africa. Citizens of Western Europe and the countries of North America were only $3.2 \%$ of all foreign students [10]. 
During this period, international scientific competitions, regular academic exchange programs, programs for international scientific cooperation and large-scale programs for attracting talented young people became active factors in the development of science in universities, academies of sciences [6]. Within the framework of these projects, the problem of readiness of lecturers was as acute as it is now, differing only in the aims and directions of training. It was important that the scientists were fluent in foreign languages and could conduct scientific debates and lectures abroad.

Until the beginning of the 1990 s, the notion of "foreign education" referred mainly to the activities of the university international departments: academic exchanges and training in foreign educational institutions. Later there appeared the term "internationalization of education" which corresponds to the ongoing process of change [33].

At the same time, new models of "export" of educational services, such as joint universities, academies of sciences branch networks, foreign representations of universities, UNESCO Chair, are emerging [28]. With the assistance of the former USSR, 66 universities, institutes, educational centers and departments were opened in more than 30 countries around the world, due to which more than 100,000 people were able to obtain higher education in accordance with Soviet standards.

Examples of such universities are the Polytechnic University, which was founded in Kabul (Afghanistan) in 1963; in Mumbai (formerly Bombay, India) in 1961-1966; in the capital of Guinea, Canada, in 1963; The Rangoon Institute of Technology in Myanmar, which was opened in 1961, the Higher School of Technical Sciences in Phnom Penh (Cambodia) and the Mining Institute in Annaba (Algeria). The practice of opening branches was also widespread: for example, the Russian State Institute of the Russian Language named after Pushkin had branches in 14 countries, which annually produced thousands of teachers of the Russian language [10].

After the collapse of the former USSR in 1991, most of the branches (universities) were closed and the support of the former partner countries ceased. Since then, other countries, including the United States, Britain and France for the first time, have occupied the niche in the educational market that used to belong to the Soviet Union.

The fourth period starts from 1991 up to the present. Now the process of internationalization of Russian universities has become a reflection of world globalization [14]. In the course of globalization, the Bologna Charter has been issued, which gave rise to the so-called Bologna Process [3]. It formed a unified European space for higher education (Russia joined in 2003) [6]. However, the very idea of harmonizing the higher education in Europe stimulated similar processes in other regions of the world.

This period, for a number of reasons, can be called very significant for higher education in Russia.

Russian universities have concentrated their efforts on participating in international research projects, maintaining the achieved level of international cooperation and providing opportunities for international mobility for students and academic staff [13].

During the fourth period, the understanding of internationalization and its implications for the development of the global "knowledge economy" was developed. Universities began to compare themselves with each other and to compete in pursuit of high internationalization indicators.

At the last stage of internationalization, not only the common language is used at universities in many countries of the world, but there also appears the EMI (English as a Medium of Instruction) program, i.e. English, as a language of instruction, and not as an academic discipline.

For EMI, English is only a means of transferring knowledge. To improve the language level is an additional task (rather, it is considered as a bonus to the EMI program). The knowledge of the academic discipline, will be evaluated, but not the language. For universities, the introduction of EMI is another step towards the internationalization of the university, as well as its integration into the international and educational environment [23].

It can be said that at present the task of internationalization of Russian Higher education is full of difficulties and contradictions, on the one hand, and interesting approaches and perspectives on the other hand. It focuses on teaching talented youth, exporting educational services and international ratings. In the first case, the main working tool is the state program "Global Education", launched in 2014, under which at least 1500 applicants will receive support for training in Master's and $\mathrm{PhD}$ programs at leading universities in the world. The second direction of work is implemented in accordance with the Con- 


\section{Теория и методика профессионального образования}

cept of the Export of Educational Services of the Russian Federation for the period from 2011 to 2020 [26, 27]. The concept supposes not only the training of foreigners outside the country, but also changes in recruiting strategies for attracting more international students to Russian universities, improving the enrolling system, teaching in English, development of open-line courses, etc. Enhancing the reputation of the Russian higher education system is also one of the tasks of the "5-100" Project/ Initiative, aimed at maximizing the competitive position of a group of leading Russian universities on the global educational and scientific market.

The South Ural State University in Chelyabinsk, Russia is one of the universities, chosen for the "5-100" Project / Initiative. Nowadays a number of academic staff has successfully passed the IELTS exams (45 lecturers in 2017) due to the "Lingua" educational program, which was launched in 2006 at SUSU. At present (2018) there are 159 members of academic staff, 77 post-graduate students and Masters, who study at different levels of the "Lingua" program.

Based on the results of the QS rating, the institutions participating in the "5-100" Project (Initiative) significantly improved their positions in the international rankings in 36 subject areas, which can be considered as the basis for the entry of five Russian universities into the first world hundred best universities by 2020 [31].

The problem of internationalization in the system of Higher education occupies one of the most important places in pedagogical discourse. Conventionally, there are four periods in the development of internationalization, which depend on the development of society and its culture.

\section{Results}

Internationalization of Higher education is a process that covers almost all areas of the modern university. These are not only external forms aimed at developing international cooperation, but also a complex internal transformation.

These processes require the direct involvement of the academic staff of the university in international mobility, being at the peak of world research, and also using modern educational technologies in the process of teaching students.

If in the middle Ages we talk about the spontaneous mobility of the academic staff and students, in the third and fourth periods it is purposeful. As for the common language of science, priority over the first and second periods was given to Latin, whereas in the third and fourth periods - to the English language. This is evidenced by the fact that most scientific articles in world-famous journals are written in English. But more convincing is the fact that an entire program of conducting classes in English - EMI has already been developed [5].

During the first decade of the XXI century the number of students has increased to 150 million [31].

On the theoretical level the problem of internationalization in Higher education began to be

\begin{tabular}{|l|}
\hline $\begin{array}{l}\text { IV Stage. From } 1991 \text { to the present. Global Common European Higher Education environment. } \\
\text { Networking and the formation of regional and global organizations and alliances. EMI program } \\
\text { in a large number of universities all over the world }\end{array}$ \\
\hline \\
\hline $\begin{array}{l}\text { III Stage. } 1950-1991 \text { The development of educational expansion and the democratization } \\
\text { of educational opportunities. The mass distribution of higher education considered as a guarantee } \\
\text { of the state's competitiveness }\end{array}$ \\
\hline $\begin{array}{l}\text { II Stage. XVIII century - the middle of XX century. The beginning and development of education } \\
\text { exports in the colonies. Mass training of academic staff for work with foreign students, a change } \\
\text { in the content of education. New forms and methods of teaching }\end{array}$ \\
\hline $\begin{array}{l}\text { I Stage. XII-XVII centuries. Spontaneous mobility of students and lecturers determined } \\
\text { by the freedom to choose training programs. Readiness to teach foreign students was provided } \\
\text { by a common language of teaching - Latin }\end{array}$ \\
\hline
\end{tabular}

Fig. 1. A retrospective analysis of the process of internationalization of higher education 
actively studied only in the third and fourth periods. Nowadays a lot of scientists and members of academic staff all over the world are interested in this phenomenon. Among them are L.P. Ryabov, J.N. Ziyatdinova, I.O. Kotlyarova, I.A. Voloshina, G.N. Serikhov, E.G. Leontyeva, E.V. Prilipko, V.I. Ivanov, P.G. Altbach, J. Knight, In. Brewstein, J. Fielden, Gu Qing, H. De Jong, H. Tikens, B. Kehm, M. Woolf and many others $[2,4,9,11,15,16,19,24,30,32,34]$.

\section{References}

1. Agibalova E.V., Donskoy G.M. Istoriya srednikh vekov [History of the Middle Ages]. Moscow, 2014. 288 p.

2. Altbach P., Knight J. The Internationalization of Higher Education: Motivations and Realities. Journal of Studies in International Education, 2007, vol. 11, no. 3/4, pp. 290-305. DOI: $10.1177 / 1028315307303542$

3. Bologna Process-European Higher Education Area. Available at: http//www.ehea.info/ (accessed 7.05.2017).

4. Brustein W. The Global Campus: Challengers and Opportunities for Higher Education in North America. Journal of Studies in International Education, 2007, vol. 11, no. 3/4, pp. 21-36. DOI: 10.1177/1028315307303918

5. Dearden J. English as a Medium of Instruction: a Growing Global Phenomenon. Available at: https://www.britishcouncil.org/sites/ default/files/e484_emi_-_cover_option_3_final_ web.pdf (accessed 28.02.2018).

6. Dubovitskaya L.I., Shvartszova A.Kh., Varkholova T.N. [Internationalization of Higher Education as Part of the Bologna Process]. Scientific Dialogue, 2013, no. 2 (14): Pedagogy, pp. 8 21. (in Russ.)

7. Education at a Glance OECD Indicators 2006. Paris, OECD Publ., 2006.

8. Enew Ch.T., Yang F. [Foreign Universities in China]. Journal of European Education, 2009, no. 1, pp. 21-36. (in Russ.) DOI: 10.1111/j.1465-3435.2008.01368.x

9. Fielden J. Private Providers of Higher Education in the United Kingdom. International Higher Education, 2010, no. 60, pp. 14-16. DOI: 10.6017/ihe.2010.60.8495

10. Galagan A.I. [International Processes in the Field of Education: Analysis of World Trends]. Social and Humanitarian Knowledge, 2002, no. 5, pp. 72-85. (in Russ.)

11. Gu Q. Maturity and Interculturality: Chinese Students' Experience in UK Higher Edu- cation. European Journal of Education, 2009, vol. 44, no. 1, pp. 37-52. DOI: 10.1111/j.14653435.2008.01369.x

12. Internatsional'noe vysshee obrazovanie: Entsiklopediya [International Higher Education: Encyclopedia]. New York, Garlend Publ., 1991. $50 \mathrm{p}$.

13. Isaeva O.N. [Integration Processes in the Field of Education as a Factor in the Formation of the Educational System: Analysis of World Trends]. Russian Scientific Journal, 2008, no. 3, pp. 161-169. (in Russ.)

14. Ivanov V.I. [Implementation of Bologna Ideas in Russia: Normative Contradictions]. Knowledge. Understanding. Skill, 2005, no. 3, pp. 70-74. (in Russ.)

15. Jong de H. The Case of University of Twente: Internationalization as Education Policy. Journal of Studies in International Education, 2013, vol. 7, no. 1. DOI: 10.1177/ 1028315302250179

16. Kehm B. Research on Internationalization in Higher Education. Journal of Studies in International Education, 2017, vol. 11, no. 3/4, pp. 433-454.

17. Kiselev S.G. Filosofiya [Philosophy]. Moscow, Yuniti Publ., 2015. 135 p.

18. Korotkova S.N. [Formation of US State Institutions]. Science, 2007, pp. 29-47. (in Russ.)

19. Kotlyarova I.O., Voloshina I.A. [Strategy and Tactics of the Additional Vocational Education Development in a Competitive University]. Bulletin of the South Ural State University. Ser. Education. Educational Science, 2018, vol. 10, no. 1, pp. 20-26. (in Russ.) DOI: $10.14529 /$ ped 180103

20. Kuznetsov S.A. Bol'shoy tolkovyy slovar' russkogo yazyka [Great Dictionary of the Russian Language]. St. Petersburg, Norint Publ., 2000. 1536 p.

21. Leont'eva E.G. Internatsionalizatsiya universitetskogo obrazovaniya: sotsial'no-filoso$f$ skiy analiz [Internationalization of Higher Education: Socio-philosophical Analysis]. Available at: www.dissercat.ru (accessed 30.12.2017).

22. Makburni G. [Globalization as a Political Paradigm of Higher Education]. Higher Education Today, 2001, no. 1, pp. 47-55. (in Russ.)

23. Minin M.G., Benson G.F., Belomestnova E.N., Pakanova V.S. [Continuous Development of Pedagogical Professionalism of Teachers of an Engineering University]. Additional Vocational Education in the Country and in the World, 2013, no. 5, pp. 41-45. (in Russ.) 


\title{
Теория и методика профессионального образования
}

24. Nayt Dzh. [Updated Definition of Internationalization]. Higher International Education, 2003, no. 33, pp. 2-3. (in Russ.) DOI: 10.6017/ihe.2003.33.7391

25. Prilipko E.V. [Opposite Points of View to Internationalization]. Polythematic net Scientific Journal of Kuban State Agricultural University, 2013, vol. 16, no. 8, pp. 1046-1054. (in Russ.)

26. Proekt povysheniya konkurentosposobnosti vedushchikh rossiyskikh universitetov sredi vedushchikh mirovykh nauchno-obrazovatel'nykh tsentrov [Project to Increase the Competitiveness of Leading Russian Universities among the World's Leading Research and Educational Centers]. Available at: http://5top100.ru/ (accessed 07.02.2018).

27. Putin V.V. O nashikh ekonomicheskikh zadachakh [About our Economic Tasks]. Available at: http://www.vedomosti.ru/politics/articles/ 2012/01/30/o_nashih_economicheskih_zadachah (accessed 28.002.2018).

28. Rukovodyashchie printsipy dlya obespecheniya kachestva $v$ transgranichnom vysshem obrazovanii (Parizh: YuNESKO, 2006) [Guidelines for Quality Assurance in Cross-border Higher Education (Paris: UNESCO, 2006)]. Available at: http://unesdoc.unesco.org/images/ 0014/001433 / 143349r.pdf (accessed 19.02.2018)

29. Seddo K.F. [Development of Higher Education in Africa]. Higher Education in Europe, 2003, vol. XXVIII, no. 1, pp. 34-35. (in Russ.) DOI: $10.1080 / 0379772032000110080$

30. Serikov G.N. [About Continuous Process of Education of a Person in Modern Reality]. Bulletin of the South Ural State University. Ser. Education, Health Care, Physical Education, 2005, no. 15, pp. 16-22. (in Russ.)

31. Statistics on Erasmus. Available at: http://ec.europa/eu/educationtoolsstatistics_en.ht $\mathrm{m}$ (accessed 28.02.2018).

32. Woolf M. Harmony and Dissonance in International Education: the Limits of Globalisation. Journal of Studies in International Education, 2002, vol. 6, no. 1, pp. 5-15. DOI: 10.1177/1028315302006001002

33. Zaretskaya S.L. Globalizatsiya $i$ obrazovanie [Globalization and Education]. Moscow, INION RAS Publ., 2001. 143 p.

34. Ziyatdinova Yu.N. [Concept Approaches to Internationalization in Engineering Education in the Developed Countries]. Bulletin of the Kazakh Technological University, 2013, vol. 16, no. 8, pp. 345-348. (in Russ.)

Received 30 March 2018

\section{РЕТРОСПЕКТИВНЫЙ АНАЛИЗ ПРОБЛЕМЫ ИНТЕРНАЦИОНАЛИЗАЦИИ В НАУЧНО-ОБРАЗОВАТЕЛЬНОЙ СФЕРЕ}

\section{E.В. Евсина}

Южно-Уральский государственный университет, г. Челябинск, Россия

\begin{abstract}
Рассматривается проблема интернационализации высшего образования на основе ретроспективного анализа проблемы. Данный процесс неотделим от процесса глобализации в различных областях человеческой деятельности. Анализируется эволюция основных тенденций, сложившихся в европейском образовании и обусловливающих необходимость интегрировать национальные образовательные системы в общеевропейское образовательное пространство. Выделяются этапы интернационализации высшего образования на основе общих критериев: мобильность научно-педагогических работников и студентов, наличие единого (общего) языка преподавания учебных дисциплин, увеличение количества университетов. Программа ЕМI рассматривается как один из результатов формирования единого общеевропейского образовательного пространства.

Ключевые слова: интернационализаџия, готовность преподавателей университета к обучению иностранных студентов, академическая мобильность, программа ЕМI (английский, как язык учебных дисииилин).
\end{abstract}




\section{Лuтература}

1. Агибалова, Е.В. История средних веков / Е.В. Агибалова, Г.М. Донской. - М., 2014. - 288 с.

2. Altbach, P. The Internationalization of Higher Education: Motivations and Realities / P. Altbach, J. Knight // Journal of Studies in International Education. - 2007. - Vol. 11, № 3/4. - P. 290-305.

3. Bologna Process - European Higher Education Area. - http //www.ehea.info/ (dama oбpaщения: 7.05.2017).

4. Brustein, W. The Global Campus: Challengers and Opportunities for Higher Education in North America / W. Brustein // Journal of Studies in International Education. - 2007. - Vol. 11, № 3/4. P. 21-36.

5. Dearden, J. English as a Medium of Instruction: a growing global phenomenon. - https:// www.britishcouncil.org/sites/default/files/e484_emi_-_cover_option_3_final_web.pdf (dama обращения: 28.02.2018).

6. Дубовиикая, Л.И. Интернационализачия высшего образования как часть Болонского проиесса / Л.И. Дубовичкая, А.Х. Шваризова, Т.Н. Вархолова // Научный диалог. - 2013. - № 2 (14). C. $8-21$.

7. Education at a Glance OECD Indicators 2006. - Paris: OECD, 2006.

8. Энью, Ч.Т. Иностранные университеты в Китае / Ч.Т. Энью, Ф. Янг // Журн. Европ. образования. - 2009. - № 1. - C. 21-36.

9. Fielden, J. Private Providers of Higher Education in the United Kingdom / J. Fielden // International Higher Education. - 2010. - № 60. - P. 14-16.

10. Галаган, А.И. Интернациональные процессы в области образования: анализ мировых тенденций / А.И. Галаган // Сои.-гуманитар. знания. - 2002. - № 5. - С. 72-85.

11. Gu, Q. Maturity and Interculturality: Chinese Students' Experience in UK Higher Education I Q. Gu // European Journal of Education. - 2009. - Vol. 44, № 1. - P. 37-52.

12. Интерначиональное высшее образование: эничкл. - Нью-Йорк: Гарлэнд, 1991. - С. 50.

13. Исаева, О.Н. Интеграционные прочессы в области образования как фактор формирования образовательной системы: анализ мировых тенденций / О.Н. Исаева // Рос. науч. журн. 2008. - № 3.- C. 161-169.

14. Иванов, В.И. Реализация болонских идей в России: нормативные противоречия / В.И. Иванов // Знание. Понимание. Умение. - 2005. - № 3. - C. 70-74.

15. Jong de, H. The Case of University of Twente: Internationalization as Education Policy / H. Jong de // Journal of Studies in International Education. - 2013. - Vol. 7, № 1.

16. Kehm, B. Research on Internationalization in Higher Education / B. Kehm // Journal of Studies in International Education. - 2017. - Vol. 11. - № 3/4. - P. 433-454.

17. Киселев, С.Г. Философия / С.Г. Киселев. - М.: Юнити, 2015. - 135 с.

18. Короткова, С.Н. Формирование государственных институтов США / С.Н. Короткова // Наука. - 2007. - C. 29-47.

19. Котлярова, И.О. Стратегия и тактика развития подразделения дополнительного профессионального образования в конкурентоспособном университете / И.О. Котлярова, И.А. Волошина // Вестник ЮУрГУ. Серия «Педагогические науки». - 2018. - T. 10, № 1. - С. 20-26.

20. Большой толковый словарь русского языка / С.А. Кузнецов. - СПб.: Норинт, 2000. - 1536 с.

21. Леонтьева, Е.Г. Интернационализация университетского образования: социально-философский анализ / Е.Г. Леонтьева. - www.dissercat.ru.

22. Макбурни, Г. Глобализачия как политическая парадигма высшего образования / Г. Макбурни // Высш. образование сегодня. - 2001. - № 1. - C. 47-55.

23. Минин, М.Г. Непрерывное развитие педагогического профессионализма преподавателей инженерного вуза / М.Г. Минин, Г.Ф. Бенсон, Э.Н. Беломестнова, В.С. Паканова // Доп. проф. образование в стране и мире. - 2013. - № 5. - C. 41-45.

24. Найт, Дж. Обновленное определение интернационализачии / Дж. Найт // Выси. междунар. образование. - 2003. - № 33. - С. 2-3.

25. Прилипко, Е.В. Полярные взгляды на глобализаџию / Е.В. Прилипко // Политемат. сетевой электрон. науч. журнал Кубанского гос. аграр. ун-та. - 2013. - Т. 16, № 8. - С. 1046-1054.

26. Проект повышения конкурентоспособности ведущих российских университетов среди ведущих мировых научно-образовательныхх иентров. - http://5top100.ru/ (дата обращения: 07.02.2018). 


\section{Теория и методика профессионального образования}

27. Путин, В.В. О наших экономических задачах. - http://www.vedomosti.ru/politics/articles/ 2012/01/30/o_nashih_economicheskih_zadachah (дата обращения: 28.02.2018).

28. Руководящие принщипы для обеспечения качества в трансграничном высшем образовании (Париж: ЮНЕСКО, 2006). - http://unesdoc.unesco.org/images/ 0014/001433/143349r.pdf (dama обращения: 19.02.2018).

29. Седдо, К.Ф. Развитие высшего образования в Африке / К.Ф. Седдо // Высш. образование в Европе. - 2003. - T. XXVIII. - № 1. - C. 34-35.

30. Сериков, Г.Н. О непрерывности образования человека в современной действительности / Г.Н. Сериков // Вестник ЮУрГУ. Серия «Образование, здравоохранение, физическая культура». 2005. - № 15. - C. 16-22.

31. Statistics on Erasmus. - http://ec.europa/eu/educationtoolsstatistics_en.htm (дата обращения: 28.02.2018).

32. Woolf, M. Harmony and Dissonance in International Education: the Limits of Globalisation / M. Woolf // Journal of Studies in International Education. - 2002. - Vol. 6. - № 1. - P. 5-15.

33. Зарецкая, С.Л. Глобализачия и образование - М.: ИНИОН РАН, 2001. - 143 c.

34. Зиятдинова, Ю.Н. Концептуальные подходы к интернационализации инженерного образования в развитых странах мира / Ю.Н. Зиятдинова // Вестник Казахского технол. ун-та. 2013. - T. 16. - № 8. - C. 345-348.

Евсина Елена Валерьевна, старший преподаватель кафедры «Иностранные языки», ЮжноУральский государственный университет, г. Челябинск, elenachel@mail.ru.

Поступила в редакцию 30 марта 2018 г.

\section{ОБРАЗЕЦ ЦИТИРОВАНИЯ}

Evsina, E.V. Retrospective Analysis of Internationalization in the Research and Education Spheres / E.V. Evsina // Вестник ЮУрГУ. Серия «Образование. Педагогические науки». - 2018. - T. 10, № 2. - C. 66-74. DOI: $10.14529 /$ ped180209

\section{FOR CITATION}

Evsina E.V. Retrospective Analysis of Internationalization in the Research and Education Spheres. Bulletin of the South Ural State University. Ser. Education. Educational Sciences. 2018, vol. 10, no. 2, pp. 66-74. DOI: $10.14529 /$ ped1 80209 